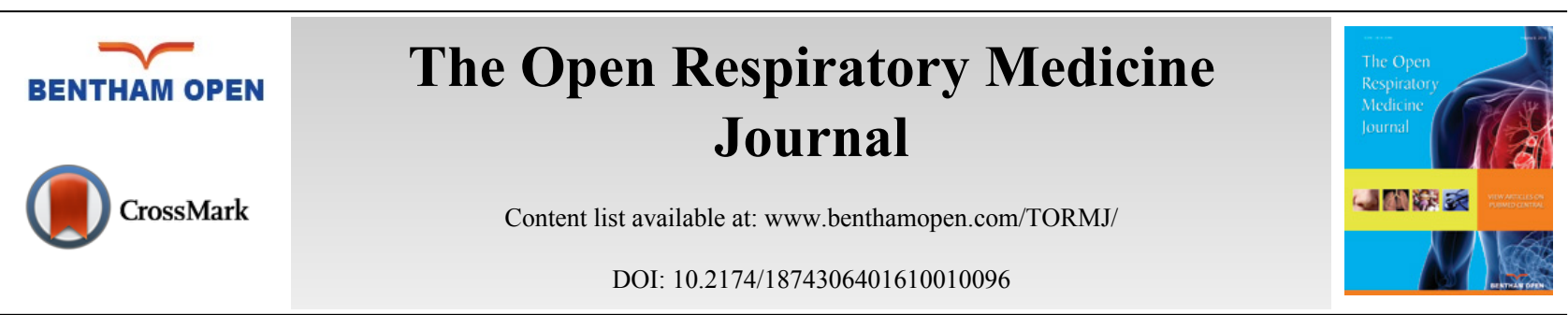

RESEARCH ARTICLE

\title{
Effect of Short-Term Exposure to High Particulate Levels on Cough Reflex Sensitivity in Healthy Tourists: A Pilot Study
}

\author{
Ryuhei Sato ${ }^{1,2,3}$, Peijun Gui ${ }^{1}$, Kumiko Ito ${ }^{1}$, Masahiro Kohzuki ${ }^{1}$ and Satoru Ebihara ${ }^{1,2, *}$ \\ ${ }^{I}$ Department of Internal Medicine and Rehabilitation Science, Tohoku University Graduate School of Medicine, Seiryo- \\ machi 1-1, Aoba-ku, Sendai 980-8574, Japan \\ ${ }^{2}$ Department of Rehabilitation Medicine, Toho University Graduate School of Medicine, Omori-nishi 6-11-1, Ota-ku, \\ Tokyo 143-8541, Japan \\ ${ }^{3}$ Department of Critical Care Nursing, School of Human Health Science, Kyoto University Graduate School of \\ Medicine, Shogoin Kawahara-cho 53, Sakyo-ku, Kyoto 606-8507, Japan
}

Received: June 14, 2016

Revised: December 05, 2016

Accepted: December 05, 2016

\section{Abstract: \\ Background:}

Previous studies have reported a relationship between particulate air pollution and respiratory symptoms or decline in lung function, but information about acute effects of short-term exposure to airborne particulate matter (PM) on cough and pulmonary function is scarce.

\section{Objective:}

To investigate the effect of short-term exposure to high concentrations of PM on the cough reflex threshold, urge-to-cough, pulmonary function, and cough-related quality of life in a group of healthy non-resident volunteers visiting Beijing, China.

\section{Methods:}

Seventeen healthy residents of Sendai, Japan, who planned to attend a meeting in Beijing, were recruited. We checked local air quality and measured cough reflex thresholds, urge-to-cough, pulmonary function, and Leicester Cough Questionnaire-acute (LCQacute) scores in the volunteers before, during, and after their trip to Beijing.

Results:

The $\mathrm{PM}_{2.5}$ and $\mathrm{PM}_{10}$ concentrations in Beijing were significantly higher than those in Japan on the measurement days. Cough reflex thresholds, expressed as nebulized citric acid concentrations required to induce $\geq 2$ and $\geq 5$ coughs, were significantly lower during the stay in Beijing than before or after the visit. Vital capacity, forced expiratory volume in one second $\left(\mathrm{FEV}_{1}\right)$, forced vital capacity (FVC), and $\mathrm{FEV}_{1} / \mathrm{FVC}$ were significantly lower during the stay in Beijing than before the trip. Similarly, the urge-to-cough threshold was significantly lower during the stay in Beijing than after the trip, as was the total LCQ-acute score.

\section{Conclusion:}

We tentatively concluded that short-term exposure to high PM concentrations may have adverse effects on cough reflex and urge-tocough thresholds, pulmonary function, and cough-related quality of life.

Keywords: Cough reflex, Particulate matter, Leicester cough questionnaire-acute, Pulmonary function, Short-term exposure, Urgeto-cough.

\footnotetext{
* Address correspondence to this author at the Department of Rehabilitation Medicine, Toho University Graduate School of Medicine, Omori-nishi 6-11-1, Ota-ku, Tokyo 143-8541, Japan; Tel: +81-3-3762-4151; Fax:+81-3-3768-6125; E-mail: satoru.ebihara@med.toho-u.ac.jp
} 


\section{INTRODUCTION}

Several studies have reported that daily changes in the levels of ambient air pollution are associated with morbidity and mortality $[1,2]$. Among the air pollutants, particulate matter (PM) has been associated with adverse health effects and therefore, extensively studied [3, 4]. The World Health Organization has set air quality guideline values for the daily mean concentrations of ambient $\mathrm{PM}_{2.5}$ (particle size smaller than $5 \mu \mathrm{m}$ ) at $25 \mu \mathrm{g} / \mathrm{m}^{3}$ and $\mathrm{PM}_{10}$ (particle size smaller than $10 \mu \mathrm{m}$ ) at $50 \mu \mathrm{g} / \mathrm{m}^{3}$. Epidemiological studies have shown associations between PM and respiratory symptoms including cough and phlegm [5 - 7]. Transient receptor potential (TRP)-class ankyrin-1 (TRPA1) and vanilloid-1 (TRPV1) ion channels are preferentially activated by environmental particulate matter, which is thought to contribute to the cough reflex [8 - 10]. Although previous reports support the hypothesis that coughing can be induced by exposure to environmental particulate matter, there are few reports on the effect of exposure to PM on cough reflex thresholds. Coughing is an important defensive reflex that removes foreign matter from the airways and there is a cognitive urgeto-cough sensory process that precedes the cough motor event [11]. In order to elucidate the association between ambient PM concentrations and cough, both cough reflex thresholds and urge-to-cough bear scrutiny.

Several laboratory-based studies have been used to examine the effects of exposure to airborne particulate matter on pulmonary function in humans $[12,13]$, but adequate research has not been carried out to measure acute changes in pulmonary function during exposure to actual day-to-day concentrations and durations of particulate air pollution.

A small group of people from Tohoku University in Sendai, Japan attended the Seventh World Congress of the International Society of Physical and Rehabilitation Medicine held at Beijing, China between June 16 - 20, 2013. Due to the rapid industrialization and urbanization during the past several decades, PM concentrations in Beijing are unusually high [14]. This led us to investigate the changes in cough sensitivity and pulmonary function among healthy volunteers from Sendai during their stay in Beijing. The principal aim of this study was to investigate the effect of short-term exposure to high PM concentrations on cough reflex thresholds, urge-to-cough, and pulmonary function in healthy subjects. The second aim was to assess the cough-specific health related quality of life before, during, and after a visit to a city with high levels of PM.

\section{MATERIALS AND METHODS}

\section{Study Participants}

We recruited 17 healthy volunteers (current smokers, $n=2$; former smokers, $n=5$; never-smokers, $n=10$ ), with a mean age of 35 years (range 25-57 years) at the Tohoku University School of Medicine. The participants had no history of airway or pulmonary disease or respiratory tract infection for 6 weeks prior to the study period and during the study period. In order to avoid any effects on cough reflex thresholds, the participants were prohibited from smoking [15], eating, and drinking for at least $2 \mathrm{~h}$ prior to the test [16]. We obtained written informed consent from each participant, and the study was approved by the Ethics Committee of the Tohoku University School of Medicine (2013-1-9).

\section{Study Design}

The study comprised 3 test days. In order to prevent potential carryover effects from previous exposures, the tests were separated by 2 weeks $[17,18]$. On the first day of testing, all measurements were conducted at Sendai, before the trip to Beijing, in order to establish a baseline. On the second day of testing, the participants were examined in the same order, over a $24 \mathrm{~h}$ period, after arriving at Beijing. The Security Export Control Office of the Tohoku University Hospital allowed us to export the device used in our research (4 June 2013). We did not restrict the movement of the participants, or the use of surgical masks was not restricted during their stay in Beijing. The average stay in Beijing was 4.0 days (range 2 - 8 days). All measurements were carried out under similar test conditions on the final day of testing, 2 weeks after returning to Sendai.

\section{Air Quality Reports}

Ambient $\mathrm{PM}_{2.5}$ and $\mathrm{PM}_{10}$ concentrations in Sendai were obtained from the Atmospheric Environmental Regional Observation System, which is controlled by the Ministry of Environment, Japan [19]. Ambient $\mathrm{PM}_{2.5}$ concentrations in Beijing were acquired from air quality monitoring data of the United States Embassy in Beijing [20]. Ambient $\mathrm{PM}_{10}$ concentrations in Beijing were obtained from Qingyue Open Environmental Data Center [21], which collates air quality data of the Chinese Ministry of Environmental Protection. The ambient $\mathrm{PM}_{2.5}$ and $\mathrm{PM}_{10}$ concentrations were expressed as the $24 \mathrm{~h}$ average on the day of testing at each of the study sites, according to the method described by Cakmak et al. 
[22]. As the environmental nitric oxide (NO) levels can affect fractional exhaled nitric oxide (FeNO) measurements [23], environmental NO was measured using an electrochemical sensor-based device (NIOX MINO, Aerocrine AB, Solna, Sweden) at the time of each test. Since the environmental NO levels in Sendai were below measurable limits $(<5$ $\mathrm{ppb}$ ) on the days of testing, the average environmental NO level was obtained from the government database [19].

\section{Cough Reflex Thresholds and Urge-to-Cough}

The cough reflex challenge was performed using nebulized citric acid under normal tidal breathing with a nose clip. The nebulized solution was delivered through an ultrasonic nebulizer (NE-U17, Omron Co. Ltd., Kyoto, Japan) [24]. The details of the measurement process have been reported elsewhere [24, 25]. In brief, a series of citric acid solutions of varying concentrations, ranging from $0.7 \mathrm{~g} / \mathrm{L}$ to $360 \mathrm{~g} / \mathrm{L}$, were delivered at two-fold incremental concentration intervals. In this study, the cough reflex threshold and suprathreshold were defined by the minimum citric acid concentration required to generate two or more coughs $\left(\mathrm{C}_{2}\right)$ and five or more coughs $\left(\mathrm{C}_{5}\right)$ in $1 \mathrm{~min}$.

The participants graded their urge to cough using a modified Borg scale ranging from 0 (no need to cough) to 10 (maximum urge to cough). The citric acid concentration that resulted in the first perceivable urge to cough without associated motor cough was defined as $\mathrm{C}_{u}$ [26]. We plotted each subject's urge-to-cough scores against the corresponding citric acid concentrations using a log-log transformation. Linear regression analysis was used to calculate the slope on a log-log scale because of the linear relationship between the concentration of the tussive agent and the urge-to-cough scores [11, 27].

\section{Pulmonary Function and Fraction of Exhaled Nitric Oxide}

Pulmonary function evaluation was conducted to measure vital capacity (VC), forced expiratory volume in one second $\left(\mathrm{FEV}_{1}\right)$, forced vital capacity $(\mathrm{FVC})$, and peak expiratory flow (PEF) by using an electronic spirometer (Chestgraph Jr HI-101, CHEST, Tokyo, Japan), in accordance with the American Thoracic Society guidelines. We measured the concentrations of FeNO using an electrochemical sensor-based device. FeNO is considered to be an useful surrogate marker for eosinophilic airway inflammation and can be used to complement conventional physiological testing [28].

\section{Cough-Specific Health Related Quality of Life}

Cough-specific health related quality of life was assessed using the Leicester Cough Questionnaire-acute (LCQacute), which consists of 19 items divided into 3 domains: physical, psychological, and social [29]. The total score ranges from 3 - 21, with lower scores indicating greater impairment of health status due to cough. We obtained the necessary permission from the developer to use the instrument and to translate it from English into Japanese. The Japanese version of the LCQ-acute was developed by Dr. Satoru Ebihara (Toho University School of Medicine), Ryuhei Sato (Tohoku University Graduate School of Medicine; Kyoto University Graduate School of Medicine), Dr. Akio Niimi (Nagoya City University Graduate School of Medical Sciences), and Dr. Haruhiko Ogawa (Ishikawa-ken Saiseikai Kanazawa Hospital). The four Japanese researchers and the developer of the original version hold the copyright for the questionnaire.

\section{Statistics}

Data are expressed as mean \pm standard deviation (SD), except when stated otherwise. Repeated measures were analyzed using repeated measures analysis of variance (ANOVA) followed by a Tukey's multiple-comparison post hoc test. A two-tailed $P$-value of $<0.05$ was considered significant. All analyses were performed using SPSS 17 software (SPSS Inc., Chicago, IL, USA).

\section{RESULTS}

The characteristics of the participants are summarized in Table $\mathbf{1 .}$

The $\mathrm{PM}_{2.5}$ concentration, on the day of testing, in Beijing $\left(43.2 \pm 9.1 \mu \mathrm{g} / \mathrm{m}^{3}\right)$ was significantly higher than $\mathrm{PM}_{2.5}$ concentrations in Sendai, before $\left(14.6 \pm 6.4 \mu \mathrm{g} / \mathrm{m}^{3}, P<0.01\right)$ and after the trip $\left(13.9 \pm 5.1 \mu \mathrm{g} / \mathrm{m}^{3}, P<0.01\right)($ Fig. 1A). Similarly, the $\mathrm{PM}_{10}$ concentration, on the day of testing, in Beijing $\left(49.3 \pm 12.4 \mu \mathrm{g} / \mathrm{m}^{3}\right)$ was significantly higher than $\mathrm{PM}_{10}$ concentrations in Sendai, before $\left(15.4 \pm 5.4 \mu \mathrm{g} / \mathrm{m}^{3}, P<0.01\right)$ and after the trip $\left(13.2 \pm 4.8 \mu \mathrm{g} / \mathrm{m}^{3}, P<0.01\right)$ 
(Fig. 1B). The ambient NO level in Beijing was significantly higher than that in Sendai $(P<0.01$ and $P<0.01$, respectively) (Fig. 1C).

As shown in Fig. (2A), the cough reflex threshold to citric acid, expressed as $\log \mathrm{C}_{2}$, during the stay in Beijing was significantly lower $(0.87 \pm 0.53 \mathrm{~g} / \mathrm{L})$ than in Sendai, before $(1.23 \pm 0.48 \mathrm{~g} / \mathrm{L}, P<0.01)$ and after $(1.16 \pm 0.50 \mathrm{~g} / \mathrm{L}, P<$ $0.01)$ the trip. Similarly, $\log \mathrm{C}_{5}$ during the stay in Beijing $(1.10 \pm 0.49 \mathrm{~g} / \mathrm{L})$ was significantly lower than before $(1.40 \pm$ $0.48 \mathrm{~g} / \mathrm{L}, P<0.05)$ and after $(1.37 \pm 0.49 \mathrm{~g} / \mathrm{L}, P<0.05)$ the trip (Fig. 2B). The urge-to-cough threshold, expressed as $\log \mathrm{C}_{\mathrm{u}}$, was also significantly lower during the stay in Beijing $(0.18 \pm 0.38 \mathrm{~g} / \mathrm{L})$ than it was after the return to Sendai $(0.38 \pm 0.31 \mathrm{~g} / \mathrm{L}, P<0.05)$ (Fig. $2 \mathrm{C})$, but there was no significant difference in the log-log slope of urge-to-cough between the 3 test days (Fig. 2D).

The results from the pulmonary function test and FeNO evaluation are shown in Table 2. Percentages of predicted $\mathrm{VC}, \mathrm{FEV}_{1}$, and $\mathrm{FVC}$, and $\mathrm{FEV}_{1} / \mathrm{FVC}$ were significantly lower in Beijing than on the pre-travel test day $(P<0.01, P<$ $0.01, P<0.01$, and $P<0.05$ ). The $\mathrm{FEV}_{1}$ and $\mathrm{FVC}$ (percent predicted) improved significantly upon the return to Sendai in comparison to the measurements made in Beijing. There was no significant difference in the levels of FeNO at any time.

The total LCQ-acute score during the stay in Beijing (19.80 \pm 1.29$)$ was significantly lower than the score after the return to Sendai $(20.55 \pm 0.71, P<0.05)$ (Fig. 3A). In particular, the physical health domain score during the stay in Beijing $(6.46 \pm 0.43)$ was lower than before $(6.71 \pm 0.33, P<0.05)$ and after the trip $(6.76 \pm 0.30, P<0.05)($ Fig. 3B).

\section{DISCUSSION}

Our preliminary study presents three findings. Firstly, the cough reflex thresholds were significantly lower during the stay in Beijing, where PM concentrations were higher than they were in Sendai before and after the trip, and the urge-to-cough threshold during the stay in Beijing was significantly lower than it was after the trip. Secondly, impaired pulmonary function was observed during the stay in Beijing as indicated by reduced $\mathrm{VC}, \mathrm{FEV}_{1}, \mathrm{FVC}_{\text {, and } \mathrm{FEV}} / \mathrm{FVC}$. Finally, the reduced cough reflex and urge-to-cough thresholds and impaired pulmonary function during the short-term exposure to high concentrations of PM were accompanied by a reduction in subjective health-related quality of life due to cough scores.

The results of the present study concur with several previous studies that have reported an association between ambient PM concentrations and increased cough or impaired pulmonary function [6, 7, 14, 30, 31]. However, there is no previous study on the association between short-term exposure to particulate matter and cough reflex sensitivity or cognition of urge to cough. Studies performed under laboratory conditions have not reported the occurrence of cough or decreased pulmonary function associated with higher PM concentrations $[12,13]$. The discordant results between the present study and the laboratory studies may be due to the extremely short exposure times, i.e., for $2 \mathrm{~h}$, in the laboratory studies.

The cough reflex originates from the stimulation of sensory neuron receptors within the respiratory tract. TRPA1 and TRPV1, which are understood to contribute to the perception of the stimulus, have shown to be a part of the afferent sensory loop of the cough reflex [32]. Recent studies have shown that TRPA1 and TRPV1 are key mediators of the cellular response to environmental particulate matter [8 - 10]. Shapiro et al. [9] have shown that TRPA1 acts as a molecular sensor for wood smoke particulate matter in sensory neurons and human adenocarcinoma lung cells. In a study of the interaction between particulate matter and the cell surface, Deering-Rice et al. [10] reported that coal fly ash, which is an insoluble particulate matter, acted as a TRPV1 agonist. Based on these findings, it is possible to speculate that TRPA1 and TRPV1 activation in relation to the environmental particulate matter may be associated with the reduction in cough reflex and urge-to-cough thresholds that were observed during a short-term stay in Beijing, although the log-log slope of urge-to-cough did not differ between Beijing and Sendai. Since the urge to cough is a component of the brain's motivation system [33], this discrepancy suggests that the primary pathway for cough due to exposure to particulate matter may not involve higher centers, such as the cerebral cortex, but rather involves the brainstem cough control area [34].

The mechanisms underlying altered pulmonary function associated with particulate matter have been examined in several studies. Activation of TRPA1 by environmental particulate matter has been reported to be an important mechanism of pneumotoxicity [8, 9]. In addition, TRPV1 activation by particulate matter in airway and alveolar epithelial cells was shown to contribute to production of immunomodulatory cytokines and chemokines and promotes apoptosis in vitro $[10,35]$. Thus, it appears that impaired pulmonary function caused by tissue damage and pulmonary 
inflammation is associated with both TRPA1 and TRPV1 activation, again potentially supporting a hypothesis that reduced cough reflex and urge-to-cough thresholds and impaired pulmonary function, observed in the present study, might have resulted from activation of TRPA1 and TRPV1 by environmental particulate matter. There was no significant difference in FeNO, which is a marker of airway eosinophilic inflammation, among the 3 test days. However, other studies have shown that humans exposed to concentrated ambient air particulate matter exhibit increased polymorphonuclear neutrophil counts [36]. Thus, our results indicate that airway inflammation by particulate matter arises from neutrophilic inflammation.

Table 1. Subject characteristics.

\begin{tabular}{|l|c|}
\hline \multicolumn{1}{|c|}{ Characteristic } & 17 \\
\hline Number & $10 / 7$ \\
\hline Male/Female & $35.4 \pm 9.6$ \\
\hline Age $($ years $)$ & $165.8 \pm 7.3$ \\
\hline Height $(\mathrm{cm})$ & $58.4 \pm 10.4$ \\
\hline Weight $(\mathrm{kg})$ & $21.1 \pm 2.5$ \\
\hline Body mass index $\left(\mathrm{kg} / \mathrm{m}^{2}\right)$ & $42.2 \pm 13.5$ \\
\hline Time from arrival in Beijing to second test $(\mathrm{h})$ & \\
\hline
\end{tabular}

Data are presented as mean \pm standard deviation (SD) unless otherwise indicated.

Table 2. Pulmonary function and fractional exhaled nitric oxide before, during, and after the stay in Beijing.

\begin{tabular}{|l|c|c|c|}
\hline \multicolumn{1}{|c|}{ Variables } & Before & During & After \\
\hline Pulmonary function & & & $108.2 \pm 12.0$ \\
\hline VC (\% predicted) & $110.7 \pm 13.8$ & $105.1 \pm 12.6^{*}$ & $96.8 \pm 13.6$ \\
\hline FEV $_{1}$ (\% predicted) & $100.4 \pm 13.2$ & $91.7 \pm 14.9^{*^{\dagger}}$ & $105.5 \pm 11.9$ \\
\hline FVC (\% predicted) & $106.0 \pm 10.9$ & $100.4 \pm 12.8^{* \ddagger}$ & $85.1 \pm 7.1$ \\
\hline FEV $_{1} /$ FVC (\%) & $87.8 \pm 5.8$ & $84.6 \pm 7.2^{\S}$ & $102.8 \pm 15.6$ \\
\hline PEF (\% predicted) & $104.4 \pm 11.8$ & $97.7 \pm 12.6$ & $22.0 \pm 13.9$ \\
\hline FeNO (ppb) & $19.9 \pm 9.6$ & $18.9 \pm 10.1$ & \\
\hline
\end{tabular}

Data are presented as mean \pm standard deviation (SD). VC, vital capacity; $\mathrm{FEV}_{1}$, forced expiratory volume in one second; FVC, forced vital capacity; PEF, peak expiratory flow; FeNO, fractional exhaled nitric oxide. ${ }^{*} P<0.01 v s$. Before; ${ }^{\dagger} P<0.05 v s$. After; ${ }^{\ddagger} P<0.01 v s$. After; ${ }^{\S} P<0.05 v s$. Before.
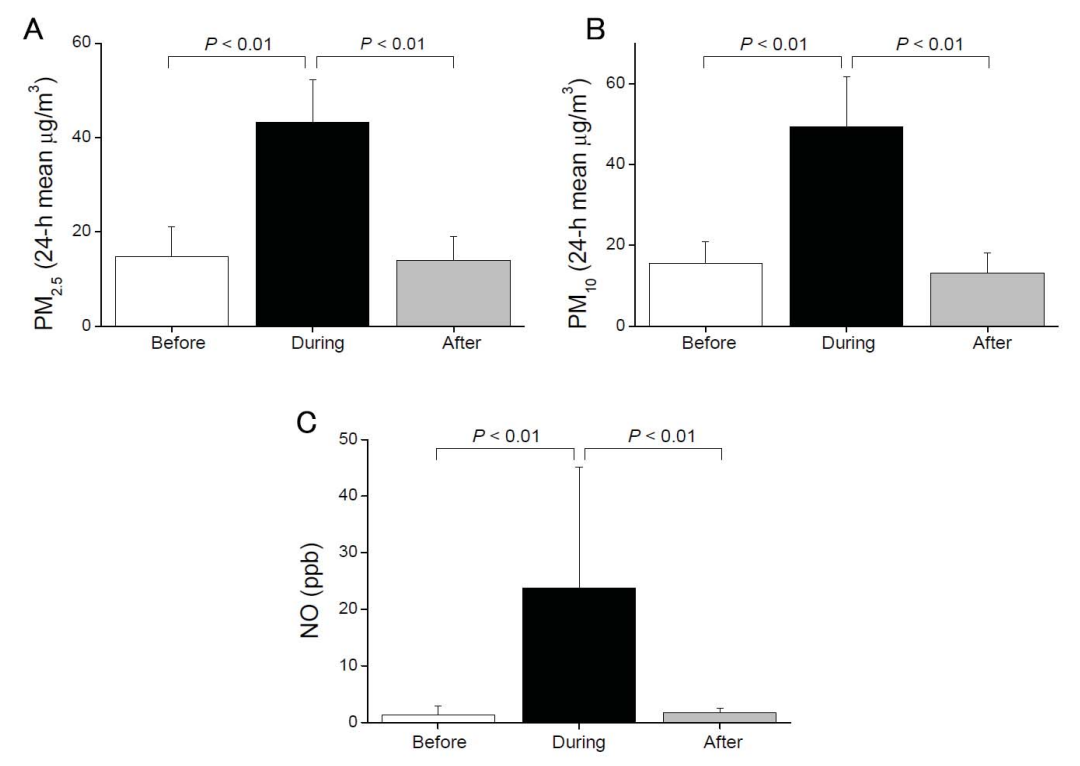

Fig. (1). Airborne particulate matter (PM) concentrations and nitric oxide (NO) measurements on the day of testing at Sendai, Japan and Beijing, China. (A) The $\mathrm{PM}_{2.5}$ concentration, expressed as a $24 \mathrm{~h}$ average, on the day of testing at Beijing was highest among the three test days. (B) The $\mathrm{PM}_{10}$ concentration, expressed as a $24 \mathrm{~h}$ average, on the day of testing at Beijing was highest among the 3 test days. (C) The ambient NO in Beijing was highest among the three test days. The bars represent the standard deviation (SD). 

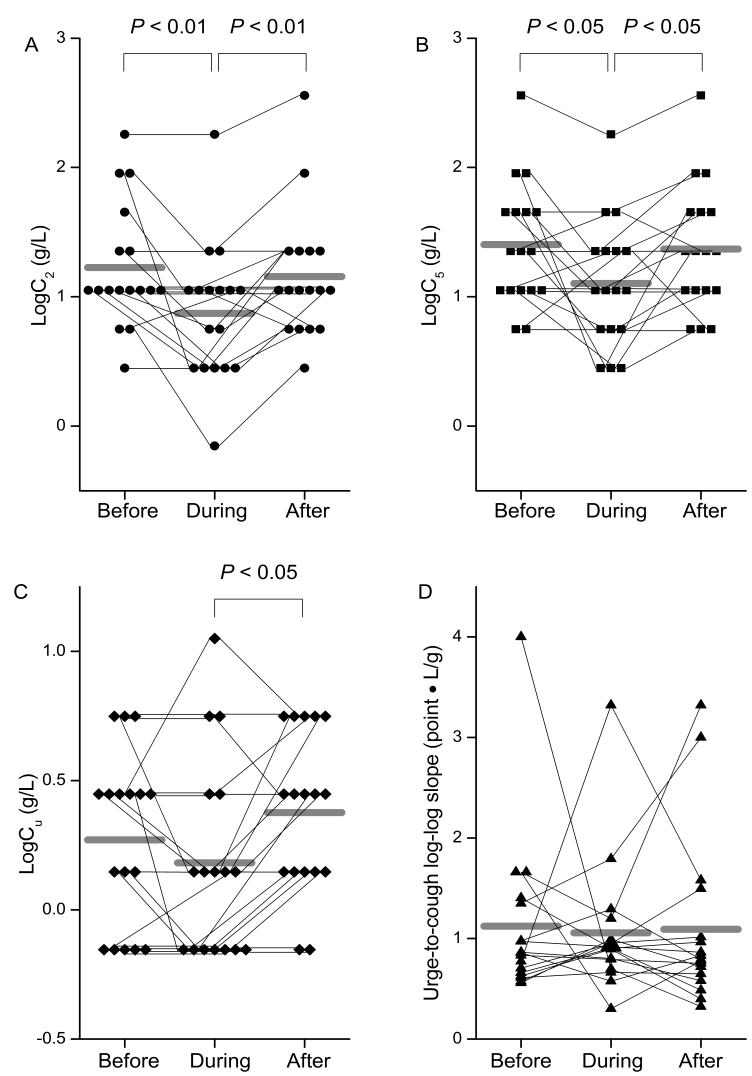

Fig. (2). Cough reflex threshold and urge-to-cough before, during, and after the stay in Beijing. (A) The cough reflex threshold is expressed as the $\log$ transformation of the lowest concentration of nebulized citric acid required to elicit $\geq 2$ coughs $\left(C_{2}\right)$. $(\mathbf{B})$ The cough reflex suprathreshold is expressed as the log transformation of the lowest concentration of nebulized citric acid required to elicit $\geq 5$ coughs $\left(\mathrm{C}_{5}\right)$. (C) The urge-to-cough threshold $\left(\mathrm{C}_{\mathrm{u}}\right)$ is defined as the lowest concentration of citric acid required to induce an urge-to-cough sensation without associated motor cough. (D) The urge-to-cough log-log slope was obtained from the linear regression of the plot between the $\log$ of citric acid concentration and the $\log$ of Borg scores. $\mathrm{C}_{2}$ and $\mathrm{C}_{5}$ values during the stay in Beijing were lowest among the three test days, and $\mathrm{C}_{\mathrm{u}}$ during the stay in Beijing was significantly lower than $\mathrm{C}_{\mathrm{u}}$ after the stay. Closed circles, squares, diamonds, and triangles indicate the values for each subject. Each gray horizontal bar represents the geometric mean value.
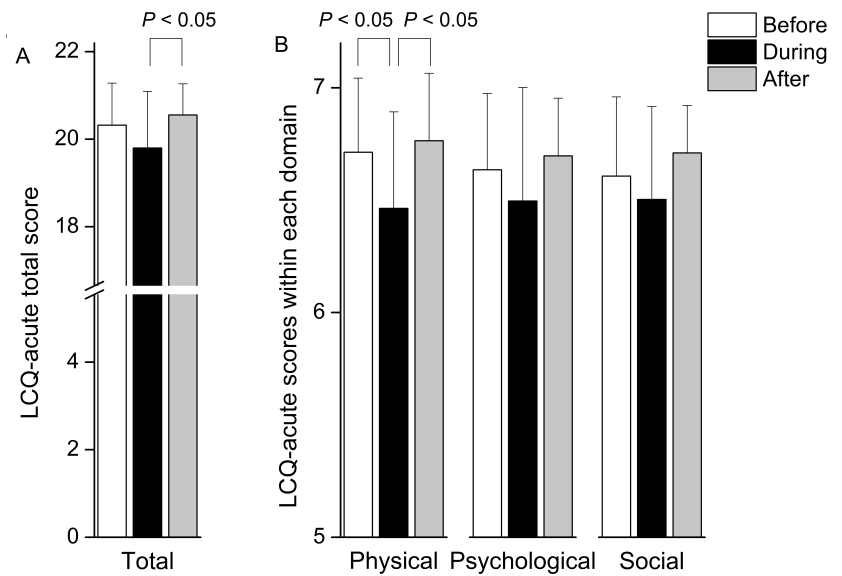

Fig. (3). Leicester Cough Questionnaire (LCQ)-acute cough-specific health related quality of life (QoL) before, during, and after the stay in Beijing. (A) Overall QoL and (B) physical, psychological, and social domains. The LCQ-acute total score ranges from 3 - 21 , with lower scores reflecting impairment of health status due to cough. LCQ-acute domain scores range from $1-7$, with lower scores indicating impairment of health status due to cough. The total score during the stay in Beijing was significantly lower than the total score after the trip and the physical health domain score during the stay in Beijing was the lowest among all test days. The bars represent standard deviation $(\mathrm{SD})$. 
Regarding the reduced LCQ-acute scores during the stay in Beijing, an association between exposure to particulate matter air pollution and LCQ score has not been reported till date, previous studies have demonstrated that the LCQ score correlates with objectively counted coughs in subjects with chronic cough [37]. We surmise that the enhanced cough sensitivity among our subjects during their stay in Beijing, at a time of high PM levels, led to the impaired health status due to cough reflected by the LCQ-acute scores. However, we did not evaluate the characteristics of the cough (e.g. intensity, frequency) in the present study.

The strong point of this study is that acute effects of air pollution on respiratory health were investigated using various factors, including cough reflex and urge-to-cough thresholds, pulmonary function, FeNO, and LCQ-acute scores, allowing the problem to be viewed from different perspectives. However, our study has limitations. Ambient air pollution is a mixture of particulate matter and gases, which may also be associated with cough [38]. Moreover, other airborne particulates, such as pollen [39], fungus [40], or passive smoking [41], may affect results of this study because these are triggers for cough. Also, travelers' fatigue could be a strong factor that affects the results of the pulmonary function test and cough reflex sensitivity test [42]. In addition, the ambient air pollution was not measured directly by us. Therefore, individual differences in exposure to particulate matter [43], and precise individual exposure estimates are unclear. Furthermore, the differences in the LCQ-acute total and LCQ-acute physical health domain scores, between the 3 days of testing, were low, despite being statistically significant [29], and the clinical importance of the differences remain unsolved, although we did use the Japanese version of the LCQ-acute, with permission from the developer. Finally, we recruited participants from the same city in Japan. In order to draw a more definitive conclusion, a larger sample study involving subjects from a wider area is warranted.

\section{CONCLUSION}

This pilot study provides data demonstrating that short-term exposure to PM concentrations, i.e., during travel, might induce changes in the cough reflex and urge-to-cough sensitivities, as well as in pulmonary function and health status due to cough. Our preliminary findings indicate acute changes in the respiratory system in a group of healthy volunteers during a stay in a city with high levels of ambient air pollutants. Exposure to particulate air pollutants in susceptible individuals, including children, the elderly, and patients with asthma or other chronic pulmonary diseases, may well pose an increased risk and this requires further investigation.

\section{CONFLICT OF INTEREST}

The authors confirm that this article content has no conflict of interest.

\section{ACKNOWLEDGEMENTS}

We thank Prof. Kefang Lai (State Key Laboratory of Respiratory Disease, Guangzhou Institute of Respiratory Disease, First Affiliated Hospital of Guangzhou Medical College) for valuable comments on the manuscript. This study was supported by Grants-in-Aid for Scientific Research from the Ministry of Education, Culture, Sports, Science and Technology, Japan (Grant numbers 25•7166, 23659375, 24300187, 24659397, 26460899, 15K12588); Research Grants for Longevity Sciences from the Ministry of Health, Labor and Welfare (H22-Junkanki-shi-Ippan-001) and Research Funding for Longevity Sciences (24-2) from National Center for Geriatrics and Gerontology (NCGG).

\section{REFERENCES}

[1] Dockery DW, Pope CA III, Xu X, et al. An association between air pollution and mortality in six U.S. cities. N Engl J Med 1993; 329(24): 1753-9. [http://dx.doi.org/10.1056/NEJM199312093292401] [PMID: 8179653]

[2] Atkinson RW, Anderson HR, Sunyer J, et al. Acute effects of particulate air pollution on respiratory admissions: results from APHEA 2 project. Air Pollution and Health: a European Approach. Am J Respir Crit Care Med 2001; 164(10 Pt 1): 1860-6. [http://dx.doi.org/10.1164/ajrccm.164.10.2010138] [PMID: 11734437]

[3] Paulin L, Hansel N. Particulate air pollution and impaired lung function. F1000 Res 2016; 5: 5. [http://dx.doi.org/10.12688/f1000research.7108.1] [PMID: 26962445]

[4] Anderson JO, Thundiyil JG, Stolbach A. Clearing the air: a review of the effects of particulate matter air pollution on human health. J Med Toxicol 2012; 8(2): 166-75.

[http://dx.doi.org/10.1007/s13181-011-0203-1] [PMID: 22194192]

[5] Pierse N, Rushton L, Harris RS, Kuehni CE, Silverman M, Grigg J. Locally generated particulate pollution and respiratory symptoms in young children. Thorax 2006; 61(3): 216-20.

[http://dx.doi.org/10.1136/thx.2004.036418] [PMID: 16396948] 
[6] Schwartz J, Neas LM. Fine particles are more strongly associated than coarse particles with acute respiratory health effects in school children. Epidemiology 2000; 11(1): 6-10. [http://dx.doi.org/10.1097/00001648-200001000-00004] [PMID: 10615836]

[7] Qian Z, Chapman RS, Hu W, Wei F, Korn LR, Zhang JJ. Using air pollution based community clusters to explore air pollution health effects in children. Environ Int 2004; 30(5): 611-20. [http://dx.doi.org/10.1016/j.envint.2003.11.003] [PMID: 15051237]

[8] Deering-Rice CE, Romero EG, Shapiro D, et al. Electrophilic components of diesel exhaust particles (DEP) activate transient receptor potential ankyrin-1 (TRPA1): a probable mechanism of acute pulmonary toxicity for DEP. Chem Res Toxicol 2011; 24(6): 950-9. [http://dx.doi.org/10.1021/tx200123z] [PMID: 21591660]

[9] Shapiro D, Deering-Rice CE, Romero EG, et al. Activation of transient receptor potential ankyrin-1 (TRPA1) in lung cells by wood smoke particulate material. Chem Res Toxicol 2013; 26(5): 750-8 [http://dx.doi.org/10.1021/tx400024h] [PMID: 23541125]

[10] Deering-Rice CE, Johansen ME, Roberts JK, et al. Transient receptor potential vanilloid-1 (TRPV1) is a mediator of lung toxicity for coal fly ash particulate material. Mol Pharmacol 2012; 81(3): 411-9. [http://dx.doi.org/10.1124/mol.111.076067] [PMID: 22155782]

[11] Davenport PW, Sapienza CM, Bolser DC. Psychophysical assessment of the urge-to-cough. Eur Respir Rev $2002 ; 12$ (85): $249-53$.

[12] Mudway IS, Stenfors N, Duggan ST, et al. An in vitro and in vivo investigation of the effects of diesel exhaust on human airway lining fluid antioxidants. Arch Biochem Biophys 2004; 423(1): 200-12. [http://dx.doi.org/10.1016/j.abb.2003.12.018] [PMID: 14871482]

[13] Gong H, Linn WS, Terrell SL, et al. Exposures of elderly volunteers with and without chronic obstructive pulmonary disease (COPD) to concentrated ambient fine particulate pollution. Inhal Toxicol 2004; 16(11-12): 731-44. [http://dx.doi.org/10.1080/08958370490499906] [PMID: 16036744]

[14] Wu S, Deng F, Hao Y, et al. Chemical constituents of fine particulate air pollution and pulmonary function in healthy adults: the Healthy Volunteer Natural Relocation study. J Hazard Mater 2013; 260: 183-91. [http://dx.doi.org/10.1016/j.jhazmat.2013.05.018] [PMID: 23747477]

[15] Kanezaki M, Ebihara S, Gui P, Ebihara T, Kohzuki M. Effect of cigarette smoking on cough reflex induced by TRPV1 and TRPA1 stimulations. Respir Med 2012; 106(3): 406-12. [http://dx.doi.org/10.1016/j.rmed.2011.12.007] [PMID: 22209625]

[16] Wise PM, Breslin PA, Dalton P. Sweet taste and menthol increase cough reflex thresholds. Pulm Pharmacol Ther 2012; 25(3): 236-41. [http://dx.doi.org/10.1016/j.pupt.2012.03.005] [PMID: 22465565]

[17] Smith R. Beijing cough: a case report. Cases J 2008; 1(1): 3. [http://dx.doi.org/10.1186/1757-1626-1-3] [PMID: 18577249]

[18] Urch B, Speck M, Corey P, et al. Concentrated ambient fine particles and not ozone induce a systemic interleukin-6 response in humans. Inhal Toxicol 2010; 22(3): 210-8. [http://dx.doi.org/10.3109/08958370903173666] [PMID: 20088738]

[19] Atmospheric Environmental Regional Observation System. [Accessed 2013 July 22]. Available from: http://soramame.taiki.go.jp/ DataMap.php

[20] BeijingAir. [Accessed 2013 July 22]. Available from: https://twitter.com/BeijingAir

[21] Qingyue Open Environmental Data Center. [Accessed 2016 May 19]. Available from: https://data.epmap.org/air/nations

[22] Cakmak S, Dales R, Leech J, Liu L. The influence of air pollution on cardiovascular and pulmonary function and exercise capacity: Canadian Health Measures Survey (CHMS). Environ Res 2011; 111(8): 1309-12. [http://dx.doi.org/10.1016/j.envres.2011.09.016] [PMID: 22000598]

[23] Society AT, Society ER. ATS/ERS recommendations for standardized procedures for the online and offline measurement of exhaled lower respiratory nitric oxide and nasal nitric oxide, 2005. Am J Respir Crit Care Med 2005; 171(8): 912-30. [http://dx.doi.org/10.1164/rccm.200406-710ST] [PMID: 15817806]

[24] Ebihara S, Saito H, Kanda A, et al. Impaired efficacy of cough in patients with Parkinson disease. Chest 2003; 124(3): 1009-15. [http://dx.doi.org/10.1378/chest.124.3.1009] [PMID: 12970031]

[25] Gui P, Ebihara S, Kanezaki M, et al. Gender differences in perceptions of urge to cough and dyspnea induced by citric acid in healthy never smokers. Chest 2010; 138(5): 1166-72. [http://dx.doi.org/10.1378/chest.10-0588] [PMID: 20847041]

[26] Dicpinigaitis PV, Bhat R, Rhoton WA, Tibb AS, Negassa A. Effect of viral upper respiratory tract infection on the urge-to-cough sensation. Respir Med 2011; 105(4): 615-8. [http://dx.doi.org/10.1016/j.rmed.2010.12.002] [PMID: 21185164]

[27] Davenport PW, Bolser DC, Vickroy T, et al. The effect of codeine on the urge-to-cough response to inhaled capsaicin. Pulm Pharmacol Ther 2007; 20(4): 338-46. [http://dx.doi.org/10.1016/j.pupt.2006.10.012] [PMID: 17292647] 
[28] Taylor DR, Pijnenburg MW, Smith AD, De Jongste JC. Exhaled nitric oxide measurements: clinical application and interpretation. Thorax 2006; 61(9): 817-27. [http://dx.doi.org/10.1136/thx.2005.056093] [PMID: 16936238]

[29] Yousaf N, Lee KK, Jayaraman B, Pavord ID, Birring SS. The assessment of quality of life in acute cough with the Leicester Cough Questionnaire (LCQ-acute). Cough 2011; 7(1): 4. [http://dx.doi.org/10.1186/1745-9974-7-4] [PMID: 21767404]

[30] Dales R, Kauri LM, Cakmak S, et al. Acute changes in lung function associated with proximity to a steel plant: a randomized study. Environ Int 2013; 55: 15-9.

[http://dx.doi.org/10.1016/j.envint.2013.01.014] [PMID: 23501476]

[31] McCreanor J, Cullinan P, Nieuwenhuijsen MJ, et al. Respiratory effects of exposure to diesel traffic in persons with asthma. N Engl J Med 2007; 357(23): 2348-58 [http://dx.doi.org/10.1056/NEJMoa071535] [PMID: 18057337]

[32] Grace MS, Dubuis E, Birrell MA, Belvisi MG. TRP channel antagonists as potential antitussives. Lung 2012; 190(1): 11-5. [http://dx.doi.org/10.1007/s00408-011-9322-3] [PMID: 21964632]

[33] Davenport PW. Urge-to-cough: what can it teach us about cough? Lung 2008; 186(Suppl. 1): S107-11. [http://dx.doi.org/10.1007/s00408-007-9045-7] [PMID: 17952695]

[34] Widdicombe J, Eccles R, Fontana G. Supramedullary influences on cough. Respir Physiol Neurobiol 2006; 152(3): 320-8. [http://dx.doi.org/10.1016/j.resp.2006.02.018] [PMID: 16621735]

[35] Agopyan N, Head J, Yu S, Simon SA. TRPV1 receptors mediate particulate matter-induced apoptosis. Am J Physiol Lung Cell Mol Physiol 2004; 286(3): L563-72.

[http://dx.doi.org/10.1152/ajplung.00299.2003] [PMID: 14633515]

[36] Lippmann M, Chen LC. Health effects of concentrated ambient air particulate matter (CAPs) and its components. Crit Rev Toxicol 2009; 39(10): 865-913. [http://dx.doi.org/10.3109/10408440903300080] [PMID: 19863385]

[37] Decalmer SC, Webster D, Kelsall AA, McGuinness K, Woodcock AA, Smith JA. Chronic cough: how do cough reflex sensitivity and subjective assessments correlate with objective cough counts during ambulatory monitoring? Thorax 2007; 62(4): 329-34. [http://dx.doi.org/10.1136/thx.2006.067413] [PMID: 17101736]

[38] Joad JP, Sekizawa S, Chen CY, Bonham AC. Air pollutants and cough. Pulm Pharmacol Ther 2007; 20(4): $347-54$. [http://dx.doi.org/10.1016/j.pupt.2006.10.013] [PMID: 17174132]

[39] Pecova R, Vrlik M, Tatar M. Cough sensitivity in allergic rhinitis. J Physiol Pharmacol 2005; 56(Suppl. 4): 171-8. [PMID: 16204790]

[40] Kamei J, Takahashi Y, Itabashi T, Hayashi S, Kawai K. Atopic cough-like cough hypersensitivity caused by active sensitization with protein fraction of Aspergillus restrictus strain A-17. Pulm Pharmacol Ther 2008; 21(2): 356-9. [http://dx.doi.org/10.1016/j.pupt.2007.09.002] [PMID: 17951087]

[41] Demoulin-Alexikova S, Plevkova J, Mazurova L, et al. Impact of air pollution on age and gender related increase in cough reflex sensitivity of healthy children in slovakia. Front Physiol 2016; 7: 54. [http://dx.doi.org/10.3389/fphys.2016.00054] [PMID: 26941651]

[42] Matsumoto H, Tabuena RP, Niimi A, et al. Cough triggers and their pathophysiology in patients with prolonged or chronic cough. Allergol Int 2012; 61(1): 123-32. [http://dx.doi.org/10.2332/allergolint.10-OA-0295] [PMID: 22377525]

[43] Avery CL, Mills KT, Williams R, et al. Estimating error in using ambient PM2.5 concentrations as proxies for personal exposures: a review. Epidemiology 2010; 21(2): 215-23.

[http://dx.doi.org/10.1097/EDE.0b013e3181cb41f7] [PMID: 20087191]

(C) Sato et al.; Licensee Bentham Open

This is an open access article licensed under the terms of the Creative Commons Attribution-Non-Commercial 4.0 International Public License (CC BY-NC 4.0) (https://creativecommons.org/licenses/by-nc/4.0/legalcode), which permits unrestricted, non-commercial use, distribution and reproduction in any medium, provided the work is properly cited. 